\title{
PENGOLAHAN LIMBAH SERBUK KAYU MENJADI BAHAN MEBEL
}

\author{
Rani Hermita \\ Universitas Potensi Utama Fakultas Seni dan Desain \\ Program Studi Desain Interior \\ ranihermita@gmail.com
}

\begin{abstract}
ABSTRAK
Tujuan penelitian ini adalah untuk memanfaatkan limbah serbuk kayu menjadi bahan pembuatan mebel, serbuk kayu bukan hal yang asing lagi dikalangan para pengerajin mebel. Metode yang digunakan dalam penelitian ini adalah metode kualitatif. Berkembangnya industri furniture dan kerajinan mebel menjadi awal menumpuknya serbuk kayu. Dari berbagai industri pengolahan yang berbahan dasar kayu yang menghasilkan sedikitnya 4 ton serbuk kayu setiap harinya dri berbagai daerah. Jumlah yang sangat besar ini menjadi perhatian tersendiri oleh para pengerajin mebel dalam penanganannya. Selain serbuk kayu yang semakin meningkat kebutuhan mebel juga semakin meningkat. Dengan kebutuhan mebel yang semakin meningkat persediaan bahan dasar pembuatan mebel pun semakin sedikit seperti kayu. Sehingga menjadi suatu masalah atau kendala yang dihadapi para pengerajin mebel dengan berkurangnya bahan dasar pembuatan mebel. Untuk memenuhi kebutuhan mebel di pasaran maka ditemukan inovasi baru untuk Menyiasasi kebutuhan mebel yang semakin meninggkat yaitu dengan mengganti kayu dengan serbuk kayu menjadi bahan dasar pembuatan mebel. Selain dapat memenuhi bahan dasar pembuatan mebel maka limbah dari serbuk kayu dapat dimanfaatkan mengurangi limbah dari serbuk kayu tersebut.
\end{abstract}

Kata Kunci: Limbah Serbuk Kayu, Mebel, Metode Kualitatif

\begin{abstract}
The purpose of this study is to utilize wood powder waste to make furniture, wood powder is not a strange thing among furniture artisans. The method used in this research is qualitative method. The development of the furniture and craft furniture industry is beginning to accumulate wood powder. From various processing industries made from wood which produce at least 4 tons of wood powder every day from various regions. This huge amount is a special concern for furniture manufacturers in handling it. Besides wood powder, the increasing demand for furniture is also increasing. With the increasing need for furniture, the supply of basic materials for furniture production is getting less like wood. So that it becomes a problem or obstacle faced by furniture craftsmen with the reduction of basic materials in making furniture. To meet the needs of furniture in the market, new innovations have been found to get around the ever increasing furniture needs, namely by replacing wood with wood powder as the basic material for making furniture. In addition to being able to fulfill the basic ingredients of furniture making, waste from wood powder can be used to reduce waste from the wood powder.
\end{abstract}

Keywords: Wood Powder Waste, Furniture, Qualitative Methods 


\section{PENDAHULUAN}

Menumpuknya limbah dari serbuk kayu yang selama ini hanya dibiarkan begitu saja dapat dimanfaatkan kembali menjadi salah satu bahan untuk pembuatan mebel. Dengan sentuhan kreatifitas dan kemampuan dalam memanfaatkan limbah serbuk kayu menjadi bahan mebel. Salah satu faktor yang mendukung dalam memanfaatkan limbah dari serbuk kayu menjadi bahan mebel karena perkembangan dan pertambahan penduduk di Indonesia yang menunjukkan angka peningkatan setiap tahunnya mengakibatkan pertumbuhan ekonomi dalam bidang mebel akan semakin meningkat, maka dibutuhkan bahan mebel yang semakin banyak jumlahnya, salah satunya kursi, tempat tidur dan papan sebagai bahan material konstruksi yang akan selalu dibutuhkan dari semua aspek pembangunan.

Secara umum, mebel merupakan furniture yang diproduksi oleh pengerajin mebel sebagai kegiatan atau untuk kebutuhan rumah tangga. Semakin dibutuhkan, maka industri mebel akan semakin tumbuh mengikuti kebutuhan masyarakat. Secara umum, mebel berfungsi sebagai furniture rumah, walaupun ada yang berfungsinya hanya sebagai furnitur struktural. mebel dalam fungsi non struktural memilki arti sebagai dinding pembatas atau partisi pada gedung serta yang memiliki nilai keindahan atau yang disebut dengan estetika. Dalam fungsi struktural, mebel memilki arti sebagai furniture rumah sebagai pelengkap tempat tinggal saja.

Mebel adalah salah satu furniture dikenal dan digunakan oleh masyarakat baik di perkotaan ataupun masyarakat di pedesaan di gunakan sebagai pelengkap atau dekorasi sebuah ruangan. Dalam hal ini dapat dilihat perkembangan tempat pembuatan mebel yang didirikan oleh pengerajin untuk memproduksi mebel. Untuk sekarang ini penggunaan serbuk kayu banyak digunakan untuk pembuatan mebel ${ }^{4}$.

Penggunaan papan untuk pembuatan mebel adanya peningkatan yang sangat pesat karena pertembahan jumlah penduduk yang semakin bertambah. Salah satu cara metode yang dapat digunakan untuk memmenuhi kebutuhan dari bahan mebel maka material pembuatan mebel disiasasi dicampur dengan serbuk gergaji untuk memenuhi kebutuhan mebel yang semakin bertambah. Berdasarkan penjelasan diatas, perlu dilakukannya penelitian yang objektif terhadap pembuatan mebel, sehingga serbuk gergaji dapat digunakan menjadi alternatif campuran yang tepat pada pembuatan mebel, dengan harapan serbuk gergaji tersebut tidak terbuang sia-sia, tetapi dapat menambah kekuatan mebel serta dapat menghasilkan mebel yang memiliki kualitas yang baik. Sehingga hasil dari penelitian ini dapat bermanfaat sebagai bahan tambahan untuk pembuatan mebel.

Serbuk kayu mengandung beberapa komponen utama yaitu, hemiselulosa, selulosa, zat lignin, dan zat ekstratif kayu. Serbuk kayu merupakan bahan berpori, sehingga air mudah terserap dan mengisi pori-pori tersebut. Dimana sifat serbuk kayu yang higroskopik atau mudah menyerap air sehingga serbuk kayu tidak bisa di buat menjadi bahan dasar pembuatan mebel tetapi serbuka kayu dapat dijadikan sebagai bahan campuran untuk pembuatan mebel ${ }^{5}$.

\section{STUDI LITERATUR}

Pengolahan serbuk kayu menjadi bahan mebel

II.1. Sebagai bahan referensi pertama dalam pengolahan serbuk kayu menjadi bahan mebel meninjau penelitian karya dari Sutopo, Trias Wurgandini, Abdul Harits Amrullah jurusan Kriya Institut Seni Indonesia. Rumusan masalah beserta pemaparan yang telah 
dilakukan pada bagian latar belakang masalah, kemudian bagaimana mengolah limbah serbuk kayu menjadi aksesoris interior dengan teknik cor. Hasil pada pembahasan penilitian ini adalah untuk menghasilkan karya-karya dari limbah serbuk kayu yang lebih bermanfaat dan bernilai ekonomis seperti hiasan dinding. Persamaan dari penelitian ini adalah sama-sama menggunakan serbuk kayu sebagai media penelitian sedangkan perbedaan dari penelitian ini adalah karya dari Sutopo dkk yang dihasilkan dari serbuk kayu adalah asesoris sedangkan hasil karya dari penulis yang di hasilkan dari serbuk kayu adalah untuk pembuatan bahan mebel ${ }^{2}$.

II.2. Sebagai bahan refensi kedua dalam pengolahan serbuk kayu menjadi bahan mebel meninjau penelitian karya dari Muhammad Ikhsan, Saifuddin, Bambang Edison, Khairul Fahmi jurusan Teknik Sipil Universitas Pasir Pengaraian. Rumusan masalah beserta pemaparan yang telah dilakukan pada bagian latar belakang masalah, kemudian bagaimana mengolah limbah serbuk kayu menjadi campuran pembuatan beton. Tujuan untuk menghasilkan beton yang mempunyai tekstur atau serat seperti serbuk kayu. Persamaan dari penelitian ini adalah media yang digunakan untuk membuat karya berasal dari serbuk kayu. Sedangkan perbedaan yang dimiliki antara penelitian karya Muhammad Ikhsan dkk menghasilkan beton sedangkan untuk karya penulis adalah untuk bahan pembuatan mebel ${ }^{1}$.

\section{PEMBAHASAN}

\section{A. Serbuk Kayu}

Serbuk kayu merupakan hasil yang didapat dari hasil penggergajian yang umumnya berasal dart tukang kayu atau pembuat mebel. Secara Umum sebuk kayu dihasilkan dari sisa pemotongan kayu ataupun sisa dari penghalusan kayu serta dikerjakan dengan alat penghalus kayu atau yang sering disebut dengan ketam kayu. Serbuk kayu mempunyai manfaat yang yang banyak apabila dijadikan sebagai bahan campuran dalam pembuatan mebel. Secara umum, produksi mebel sangat berkembang pesat pada sekarang ini, sehingga untuk memenuhi kebutuhan pembuatan mebel mencari alternatif lain untuk tidak memakai bahan kayu utuh dalam membuat mebel. Sehingga secara umum mebel di produksi menggunakan campuran serbuk kayu dikerjakan untuk meminimalis harga dari produksi, sehingga beberapa produk mebel, seperti lemari dan perabotan lainnya dapat dijual dengan harga yang lebih murah dari pada mebel yang terbuat dari kayu asli.

Pada zaman dahulu furniture atau mebel terbuat dari kayu utuh tanpa sambungan agar lebih kokoh karena ketabalannya. Karena pada sekarang ini persediaan kayu yang terbatas kemudian orang membuat furniture dengan menggunakan kayu yang disambungsambung agar menghasilkan mebel. Sekarang ini persediaan kayu semakin langka sehingga limbah kayu pun dimanfaatkan dan diolah menjadi kayu lapis untuk mebel, Particle Board sendiri terbuat dari sisa pengerjaan kayu seperti serbuk kayu, potongan kayu, serpihan kayu dan bahan kimia resin yang direkatkan dengan tekanan tinggi dan kemudian dikeringkan. Dalam proses finishingnya, permukaan particle board. 


\section{Serbuk Kayu Sebagai Bahan Campuran Pembuatan Mebel}

Untuk mensiasati kurangnya bahan dasar pembuatan mebel seperti kayu dapat menggantinya dengan serbuk kayu karena memiliki manfaat yang baik sebagai bahan campuran dalam pembuatan mebel. Biasanya, beberapa pengerajin mebel saat ini sudah tidak menggunakan bahan kayu utuh untuk membuat mebel tetapi sudah mulai menggunakan serbuk kayu sebagai bahan campuran untuk pembuatan mebel. Hal ini dilakukan untuk mengurangi penggunaan kayu utuh dan menekan biaya produksi, sehingga produk mebel yang terbuat dari campuran serbuk kayu, seperti lemari dan mebel lainnya dapat dijual dengan harga yang lebih murah. Ada beberapa keuntungan dari produk mebel yang dicampur serbuk kayu diantaranya:

- Biaya dari produksi pembuatan mebel dapat lebih murah

- Harga jual dari mebel yang terbuat dari serbuk kayu lebih murah

- Bobot mebel yang terbuat dari kayu juga lebih ringan

Namun dengan demikian selain memiliki kelebihan mebel yang terbuat dari bahan campuran serbuk kayu, ada beberapa kelemahan dari produk mebel yang dibuat dengan menggunakan campuran serbuk serbuk kayu. Berikut ini ada beberapa kelemahan dari mebel yang dibuat menggunakan bahan campuran dari serbuk kayu:

- Mebel yang terbuat dari serbuk kayu tidak tahan lama

- Mebel yang terbuat dari serbuk kayu mudah lapuk dan di makan rayap

- Sering menimbulkan kotoran yang terjatuh dilantai

- Sangat rapuh apabila tidak di rawat dengan baik

\section{B. Mebel}

Mebel atau furniture merupakan peralatan rumah tangga yang meliputi semua barang seperti kursi, meja, dan lemari dan hiasan. Mebel berasal dari kata movable, yang artinya bisa bergerak. Pada zaman dahulu meja kursi dan lemari relatif mudah digerakkan dari batu besar, tembok, dan atap. Sedangkan kata furniture berasal dari bahasa Prancis fourniture. Fourniture mempunyai asal kata fournir yang artinya furnish atau perabot ruangan atu rumah. Walaupun mebel dan furniture mempunyai arti yang beda, tetapi yang ditunjuk sama yaitu meja, kursi, lemari, dan seterusnya. Dalam kata lain, mebel atau furniture adalah semua benda yang ada di dalam rumah dan digunakan oleh penghuninya ukursi untuk duduk, tempat tidur untuk berbaring, ataupun lemari yang digunakan untuk menyimpan benda-benda kecil seperti pakaian atau perlengkapan dapur seperti gelas, piring, cangkir dan sendok. Mebel ada yang terbuat dari kayu, papan, kulit dan serbuk kayu atau yang sering disebut dengan gergaji kayu ${ }^{6}$.

Untuk pembuatan mebel dari serbuk kayu terbilang cukup sederhana karena hannya memerlukan beberapa bahan tambahan seperti resin dan air untuk menghasilkan sebuah mebel dari serbuk kayu. Bahan dasar yang paling penting dalam pembuatan mebel adalah serbuk kayu yang berasal dari sisa pemotongan kayu kemudian dipilih berdasarkan jenis dari sisa serbuk kayu tersebut. Kemudian diolah menggunakan mesin press.

\section{Fungsi Mebel}

Fungsi mebel sangat berpengaruh pada ruangan, bukan hannya untuk memperindah tampilan ruangan mebel juga berfungsi untuk peralatan rumah tangga yang dibutuhkan. Jika 
dilihat dari segi karya seni mebel mempunyai fungsi untuk mendukung aktifitas manusia sehari-hari. Sebagai penjelasan, mebel merupakan sebuah karya seni yang mempunyai nilai, tradisi, sumberdaya di lingkungan sekitar, mebel merupakan kebutuhan dari kehidupan manusia, dan perilaku atau pola pikiran manusia, dimana kesenian itu hidup dengan adanya kreatifitas dalam pengolahan atau pembuatan mebel itu sendiri ${ }^{3}$.

Untuk menciptakan mebel yang indah serta mempunyai nilai estetik dan simbolis yang tinggi sangat menuntut kreatifitas pengerajinnya. Karena untuk dapat dikatakan karyanya mebel secara kreatif, pembuatan mebel harus mampu menciptakan keunikan baru pada rancangan mebel yang dapat dilihat dan kepandaiannya menemukan hal-hal yang baru oleh para pengerajinnya. Keberadaan usaha mebel sangat dipengaruhi tuntutan masyarakat sekitar, akan tetapi dengan meningkatnya jumlah produk dari mebel dan terbatasnya bahan baku untuk membuat mebel maka disini para pengerajin mebel beralih dari bahan dasar papan asli menjadi menggunakan serbuk kayu sisa dari gergaji untuk membuat mebel.

Selain serbuk kayu yang digunakan untuk pembuatan bahan mebel dan mengetahui lebih jelas tentang beberapa macam jenis kayu dalam pembuatan mebel dapat dijelaskan sebagai berikut ${ }^{7}$ :

\section{a. Kayu Solid}

Kayu solid merupakan bahan baku pembuatan furniture atau mebel untuk interior ruangan maupun interior outdoor yang merupakan bahan baku yang paling kuat dibandingkan dengan bahan kayu yang telah diolah, tetapi dikarenakan jumlah tanaman dan jangka waktu yang relatif lama dan untuk proses penebangan pohon yang tidak memiliki seimbangan menyebabkan persedian kayu solid terbatas dan susah untuk didapatkan kemudian untuk kayu solit memiliki harga yang lebih mahal disbanding dengan kayu yang sudah diolah ${ }^{7}$.

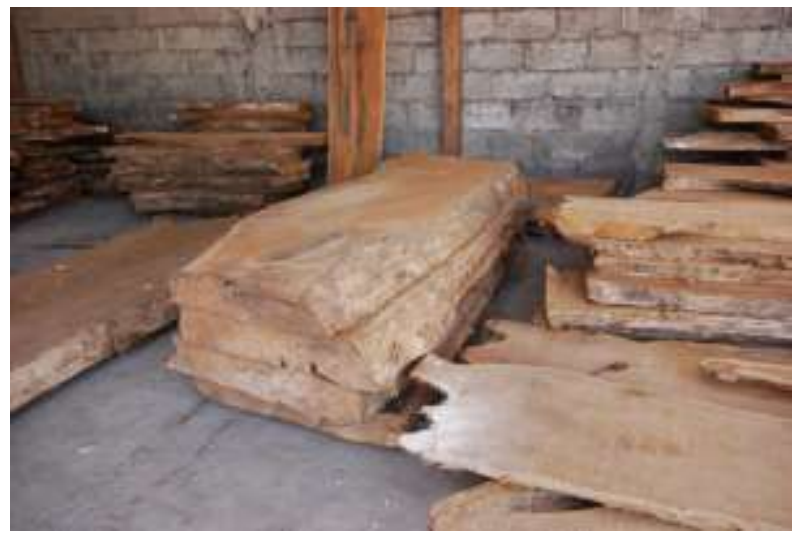

Gambar 1 : Salah Contoh Dari Kayu Solid

Sumber : https://jasafurniture.wordpress.com/bahan-baku-furniture/

\section{b. Jenis Papan Plywood}

Jenis kayu plywood merupakan bahan yang paling sering digunakan dalam pembuatan barang furniture atau mebel terutama untuk barang interior dan barang-barang furniture atau mebel yang terdapat di dalam ruangan yang terlindung dari sinar matahari dan hujan. Harganya dari jeneis kayu plywood relatif lebih murah dari pada harga kayu solid. Kayu jenis plywood merupakan bahan dari kayu olahan dan relatif lebih kuat dibandingkan 
dengan jenis kayu olahan lainnya seperti blockboard, partikelboard, mdf. Plywood berbahan dasar dari lapisan-lapisan kayu yang ditumpuk berlapisdan dipress jenis kayu plywood ini biasanya terbuat dari beberapa jenis kayu diantaranya dari kayu jati, rambuatan, kayu mahanoni, dan kayu nagka. Dengan kualitas yang lebih baik dibandingkan kayu olahan lainnya, hal ini menyebabkan mebel yang terbuat dari plywood mempunyai harga yang lebih mahal bila dibandingkan dengan beberapa jenis kayu olahan lainnya ${ }^{7}$.

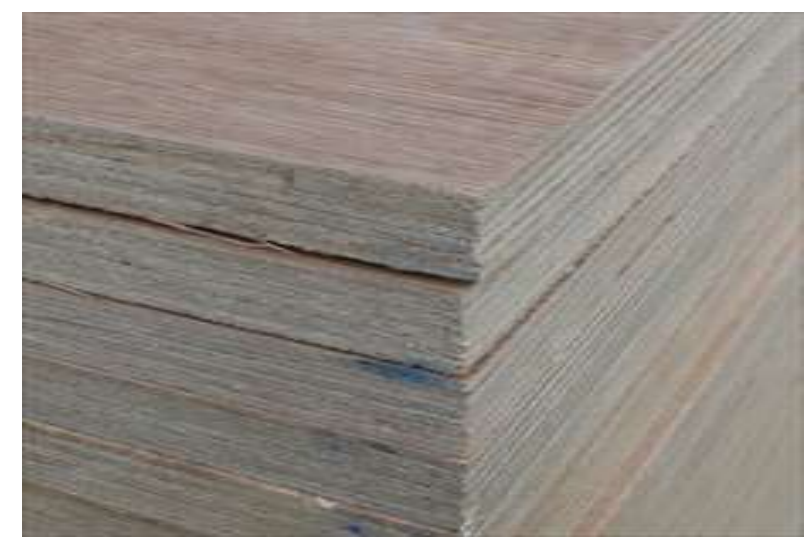

Gambar 2 : Salah Contoh Dari Papan Jenis Plywood Sumber : https://jasafurniture.wordpress.com/bahan-baku-furniture/

\section{c. Jenis Papan Blockboard}

Jenis papan dari Blockboard memiliki harga sedikit lebih murah dibanding plywood begitu juga dengan kwalitasnya. Papan jenis ini terbuat dari kumpulan kayu berbentuk kotak kecil yang rekatkan dan dipadatkan oleh mesin yang diberi lapisan di kedua sisinya, dimana lapisannya dapat menggunakan beberapa jenis kayu diantaranya adalah kayu jati ataupun kayu mahoni, sebagai referensi atau contoh kayu olahan maka penulis mengambil salah satu contoh jenis papan blockboard untuk rujukan penelitian penulis ${ }^{7}$.

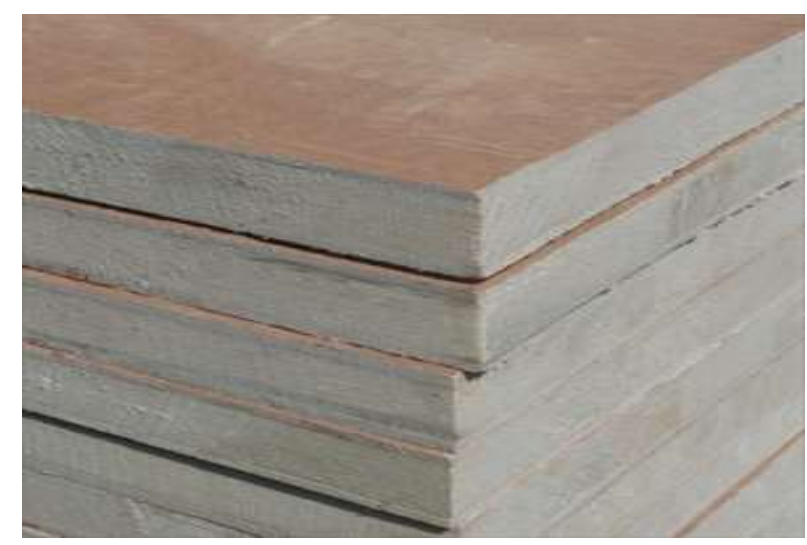

Gambar 3 : Salah Contoh Dari Papan Jenis Blockboard Sumber : https://jasafurniture.wordpress.com/bahan-baku-furniture/

\section{d. Papan Jenis MDF}

Papan jenis MDF yang terbuat dari serbuk kayu halus dan bahan kimia yang disebut dengan resin yang direkatkan dan kemudian dipadatkan atau di prss. Jenis kayu yang 
digunakan dalam pembuatan papan MDF biasanya diambil dari kayu sisa perkebunan ataupun bambu. Sehingga jenis papan MDF lebih ramah lingkungan. Bentuk dari papan MDF berbentuk lembaran. Versi yang lebih padat dan lebih kuat dan dikenal dengan sebutan dari HDF (High Density Fibreboard). MDF harganya sedikit lebih murah dari pada plywood dan blockboard. Papan jenis MDF diproses menyerupai bahan kertas yang tebal dan kuat. Papan jenis MDF biasanya digunakan pada mebel yang fabrikasi yang dijual dalam bentuk sudah "jadi" biasanya pelapis luarnya kertas mempunyai bentuk bertexture. Jenis papan MDF banyak dipakai sebagai bahan dasar mebel import. Untuk membandingkan hasil penelitian disini penulis mengambil salah satu contoh jenis papan MDF sebagai bahan perbandingan ${ }^{7}$.

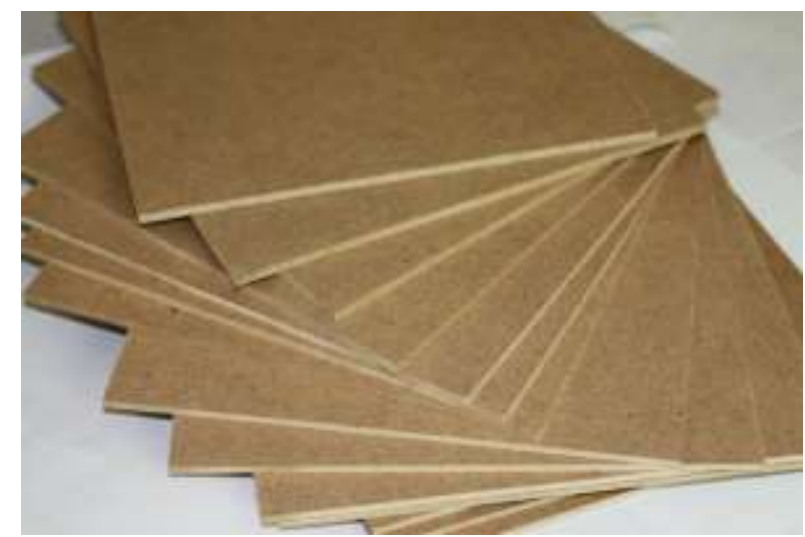

Gambar 4 : Salah Contoh Dari Papan Jenis MDF Sumber : https://jasafurniture.wordpress.com/bahan-baku-furniture/

\section{e. Papan Jenis Partikel Board}

Papan yang berjenis partikel board terbuat dari bahan sisa pekerjaan kayu seperti serbuk gergaji atau yang paling umum dengan sebutan serbuk kayu, serpihan kayu, potongan kayu kecil dan juga menggunakan bahan kimia resin yang berfungsi untuk merekatkan dan proses pengerjaan nya dilakukan dengan cara memberikan tekanan tinggi dan kemudian dikeringkan melalui paparan sinar matahari. Jenis papan partikel board memiliki kondisi papan yang kurang baik apabila menginginkan interior yang bertahan lama dan apabila tempat tinggal rawan banjir karena akan mudah rusak dan lapuk. Jenis papan ini adalah jenis papan olahan yang paling rendah kelasnya. Jenis papan partikel board sangat rentan air dan menyerap air, karena berbahan dasar serbuk kayu kasar atau serbuk kayu halus yang dipress dengan tekanan tinggi sehingga memiliki pori-pori yang lebih besar dibandingkan mdf atau hdf, sehingga mudah menyerap air dan tidak kuat menahan beban berat seperti jenis papan lainnya. Tetapi untuk menanggulangi terbatasnya bahan baku untuk pembuatan mebel maka jenis papan dari serbuk kayu ini sudah banyak digunakan untuk pembuatan mebel. Selain murah jenis papan partikel board ini juga memiliki bobot yang ringan sehingga mudah untuk dipindahkan. Untuk ketahanan dari semua jenis mebel yang terbuat dari papan olahan. Dalam mendukung dan perbandingan penelitian ini penulis mengambil salah satu contoh papan jenis partikel board sebagai referensi untuk penulisan karya ilmiah ini ${ }^{7}$. 


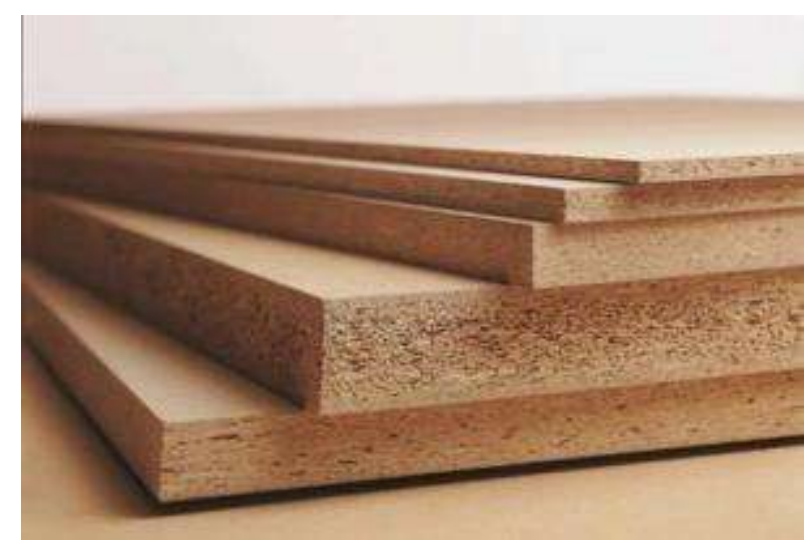

Gambar 5 : Salah Contoh Dari Papan Jenis Partikel Board Sumber : https://jasafurniture.wordpress.com/bahan-baku-furniture/

\section{f. Metode Penciptaan}

Pada pengolahan untuk pembuatan mebel dari sisa serbuk kayu metode yang digunakan beberapa metode pengumpulan data diantaranta:

1. Metode Pengumpulan data

Dalam pengolahan serbuk kayu menjadi mebel terdapat beberapa metode pengumpulan data dalam penelitian ini yaitu menggunakan metode kualitatif, yaitu metode perancangan yang berbasis riset, data yang dikumpulkan untuk membuat serbuk kayu menjadi bahan mebel. Data yang dikumpulkan dalam penelitian ini terbagi menjadi dua yaitu data primer dan data sekunder:

a. Data primer

Adapun data primer yang penulis peroleh merupakan hasil pengamatan di lapangan yaitu sebagai berikut:

1. Bagaimana pengolahan serbuk kayu menjadi mebel.

2. Belum banyak yang memanfaatkan serbuk kayu menjadi bahan mebel.

3. Terbatasnya pengetahuan tentang pengolahan serbuk kayu menjadi mebel.

\section{b. Data Sekunder}

Dalam pengolahan serbuk kayu menjadi mebel juga diperlukan data sekunder yaitu data yang didapat dari keterangan dan informasi, dari karya-karya tulis yang berkaitan dengan pembuatan mebel dari serbuk kayu. Data sekunder ini digunakan untuk memperkuat data-data primer yang telah penulis dapatkan, data sekunder ini mudah didapat dan bermanfaat guna perumusan masalah.

\section{Metode Analisa Data}

Dalam pengolahan serbuk kayu menjadi mebel tentunya diperlukan metode analisis atau langkah-langkah dalam riset dan proses kreatifitas, berikut adalah langkah-langkah dalam pengolahan serbuk kayu menjadi mebel.

\section{a. Persiapan}

Proses pengolahan serbuk kayu menjadi mebel dilakukan persiapan berupa studi visual mebel dengan cara melakukan pengamatan langsung tehadap bagaimana cara pengolahan serbuk kayu menjadi mebel. Pengamatan dilakukan 
mulai dari pengumpulan data yang dilakukan seperti observasi, dokumentasi, wawancara dan studi pustaka. Data yang didapat dari kegiatan di atas dijadikan pedoman dalam menggarap karya. Pada proses pengolahan serbuk kayu menjadi.

b. Studi Pustaka.

Pada pengolahan serbuk kayu menjadi mebel dilakukan studi pustaka dalam Desain Komunikasi Visual guna menentukan berbagai sumber yang berkaitan dengan objek penciptaan yakni menelusuri data berupa artikel, video, buku, laporan penciptaan ataupun tulisan yang berkaitan dengan objek, sebagai referensi guna memperluas wawasan yang didapatkan.

Observasi suatu cara dalam pengumpulan data untuk penelitian, penulis mengumpulkan data dengan mengamati secara langsung pada kajian atau proses yang terjadi dilapangan. Observasi dilakukan pada bahan maket yang akan digunakan dan alat-alat.

\section{Teknik Analisa Data}

Pengolahan serbuk kayu menjadi mebel ini menggunakan metode analisa $5 \mathrm{~W}+1 \mathrm{H}$ hal ini penting metode analisa data ini untuk menjawab pemecahan masalah dalam proses pengolahan serbuk kayu menjadi mebel.

1. $5 \mathrm{~W}+1 \mathrm{H}$ :

a. What, apa yang akan dibuat? Rancangan yang akan dibuat yaitu pengolahan serbuk kayu menjadi mebel sebagai sumber ide gagasan.

b. Where, dimana akan diaplikasikan atau diterapkan? Pengolahan serbuk kayu nantinya akan diaplikasikan kedalam rancangan kebutuhan pembuatan mebel.

c. Who, Siapa target sasaran? Pada pengolahan serbuk kayu menjadi mebel target sasaran adalah seluruh seluruh pengerajin mebel.

d. When, kapan dimulai? Pada pengolahan serbuk kayu untuk pembuatan mebel dimulai sejak sekarang dan selanjutnya.

e. Why, mengapa diciptakan? Mempermudah untuk pengolahan serbuk kayu menjadi mebel.

f. How, bagaimana pengolahan serbuk kayu menjadi mebel tersebut? Serbuk kayu yang digunakan haruslah mampu memberikan pengetahuan tentang pembuatan mebel.

\section{Kajian Konsep}

Setelah mandapatkan data-data dari hasil analisa akan digunakan untuk merancang konsep perancangan. Hasil analisa data yang didapat digambarkan pada konsep perancangan yang lebih jelas. Konsep yang digunakan dalam pengolahan serbuk kayu menjadi mebel konsep terdiri dari dua yaitu, konsep visual dan konsep verbal. Konsep ini akan digunakan pada tahapan perancangan mulai dari pemilihan jenis serbuk kayu menjadi bahan mebel.

\section{Visualisasi Perancangan}

Setelah malakukan kajian konsep perancangan tahapan selanjutnya adalah visualisasi perancangan. Visualisasi perancangan terdiri dari bentuk-bentuk awal dari setiap pembuatan mebel. Tahapan ini merupakan akhir dari perancangan yang menghasilkan rancangan final.

\section{Bahan dan Alat Yang Di Gunakan}

- Serbuk Kayu 
- Karung Goni Plastik

- Alat Press Serbuk Kayu

- Air

- Drum Pengolahan

- Pemanas

- Pengaduk Manual atau Otomatis

- Cetakan

- Tepung Tapioka

- Gergaji

Proses Pembuatan Mebel Dari Serbuk Kayu

1. Masukan air ke dalam wadah atau drum besar kemudian panaskan drum diatas api

2. Kemudian setelah air yang dimasak tadi sudah mendidih masukkan resin sekitar $30 \%$ dari jumlah air lalu aduk-aduk secara terus menerus

3. Setelah kurang lebih dari 3 menit masukan serbuk gergaji yang sudah diayak untuk misahkan serbuk gergaji dengan sampah sekitar $60 \%$ dari jumlah air dengan resin aduk terus menerus sehingga menjadi seperti bubur yang kental.

4. Setelah semua tercampur masukkan bubur serbuk kayu kedalam mesin press untuk di direkatkan dan dibentuk

5. Kemudian keluarkan serbuk gergaji dari mesin press untuk di cetak dan di keringkan

\section{Proses Pembuatan Mebel}

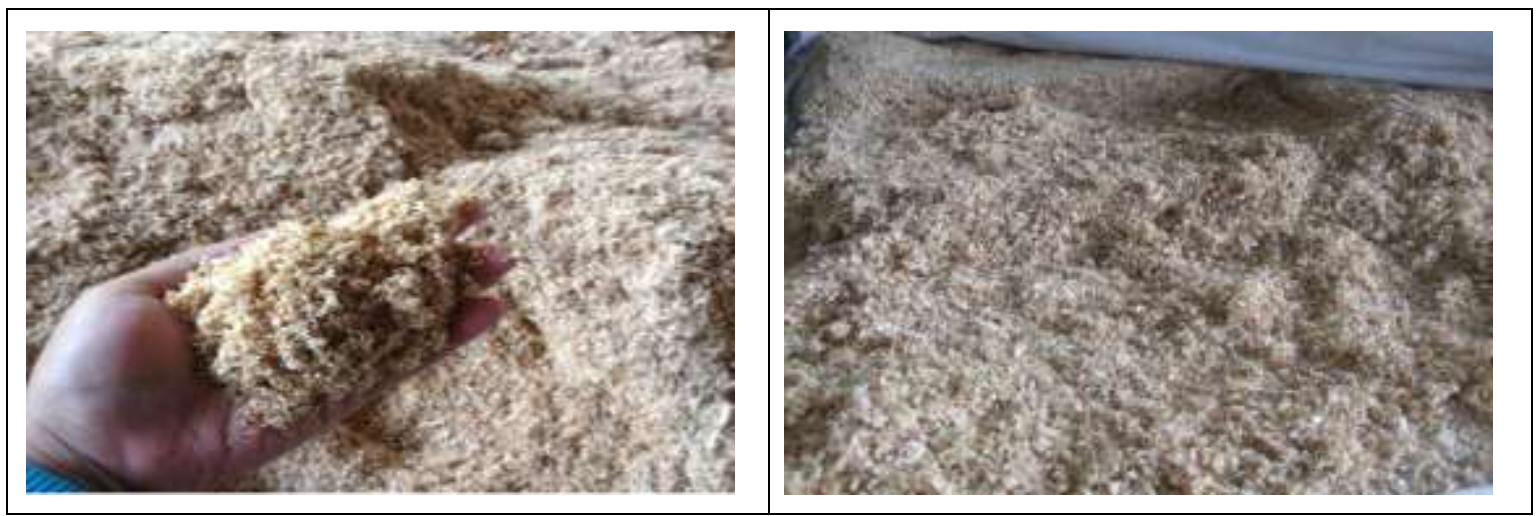

Gambar 6 : Proses Pemilihan Serbuk Kayu

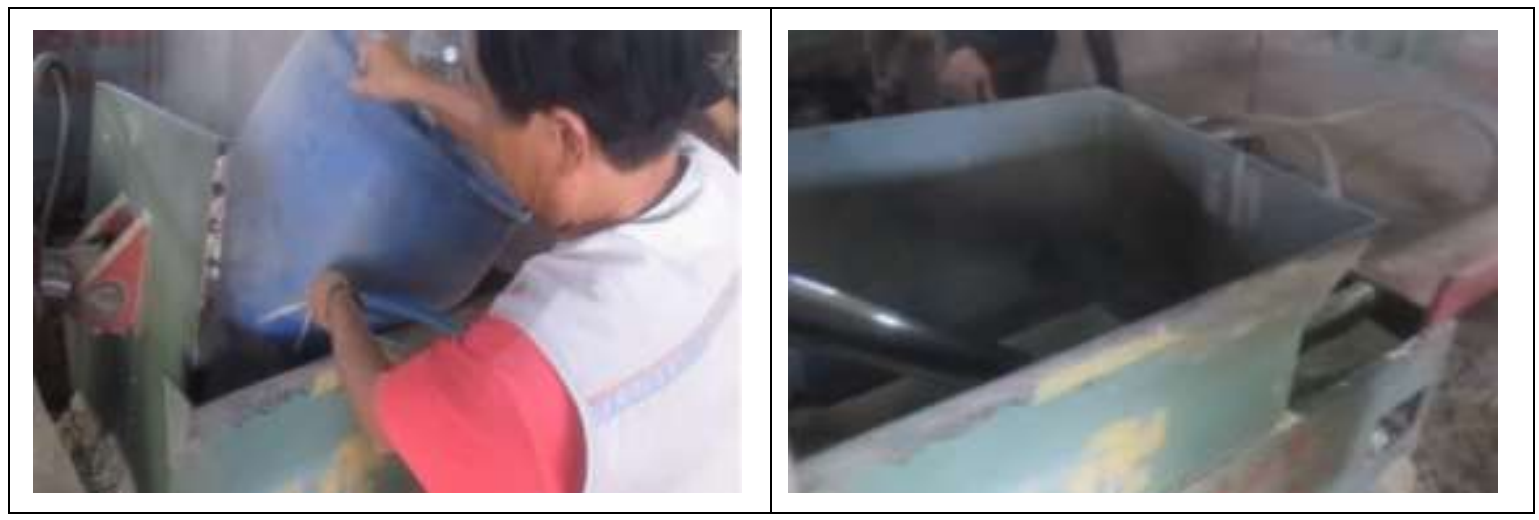

Gambar 7 : Proses Memasukkan Serbuk Kayu Ke Mesin Press 


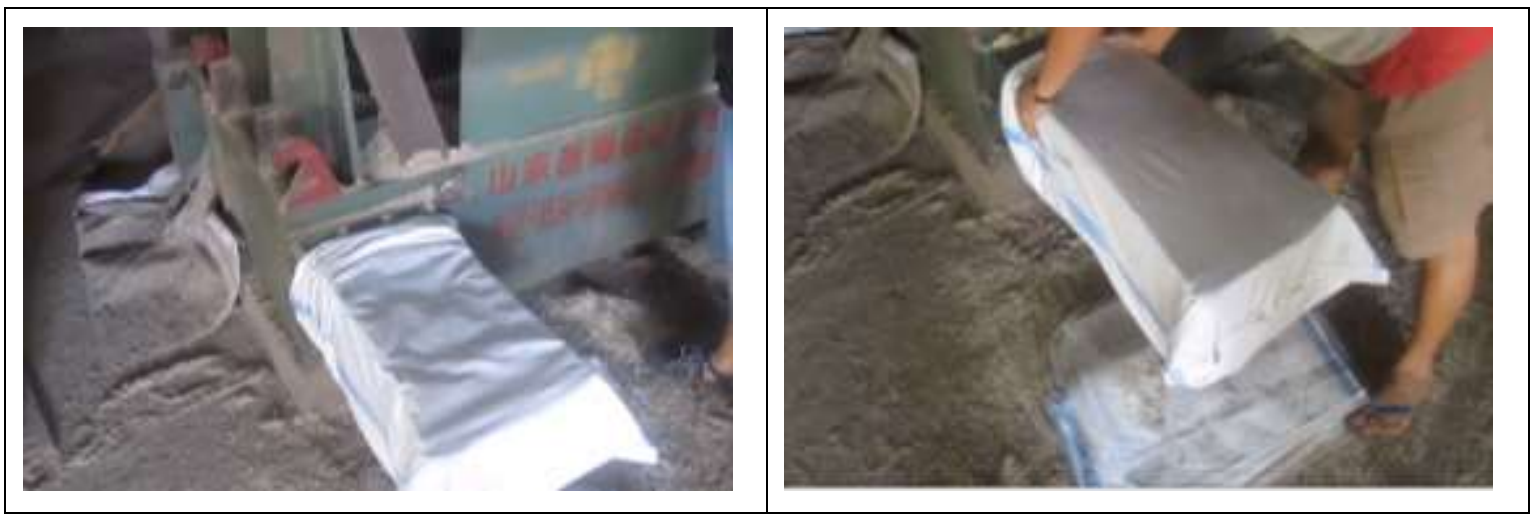

Gambar 8 : Proses Pengeluaran Hasil Press Serbuk Kayu

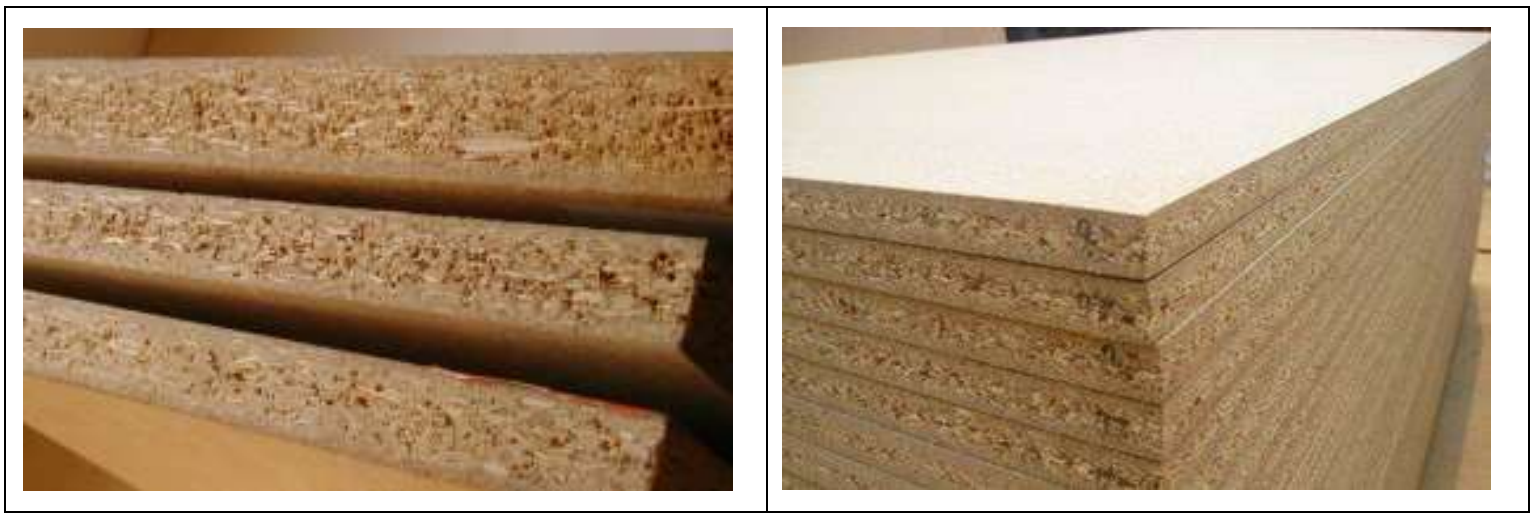

Gambar 9 : Hasil Pengolahan Serbuk Kayu Yang Sudah Jadi Menjadi Mebel

\section{KESIMPULAN DAN SARAN}

\section{A. Kesimpulan}

Dengan perkembangan zaman dan dan bertambahnya jumlah penduduk. Maka kebutuhan dari mebel juga berkembang pesat. Dengan bertambahnya kebutuhan mebel, maka bahan dasar pembutuan mebel juga ikut meningkat. Sehingga dibutuhkan alternatif lain untuk memenuhi kebutuhan dari pembuatan mebel tersebut. Maka untuk memenuhi bahan dasar untuk pembuatan mebel yaitu memanfaatkan dari limbah serbuk kayu. Untuk mendapatkan serbuk kayu tidak terlalu sulit karena bisa didapatkan dimana saja untuk memenuhi kebutuhan pembuatan mebel.

\section{B. Saran}

Sebaiknya dalam memanfaatkan limbah serbuk kayu untuk pembuatan mebel menggunakan limbah serbuk kayu yang memiliki kuawalitas yang baik. Kelebihan dari pemanfaatan limbah serbuk kayu selain mudah didapatkan serbuk kayu harga dari serbuk kayu jauh lebih murah. Selain ada kelebihan mebel yang terbuat dari serbuk kayu juga memiliki kekurangan yaitu mebel yang terbuat dari bahan dasar serbuk kayu mudah lapuk dan tidak tahan lama. 


\section{DAFTAR PUSTAKA}

[1] Ikhsan, Saifuddin Muhammad, Edison Bambang, Fahmi Khairul. (2014). Pengaruh Penambahan Campuran Serbuk Kayu Terdahap Kuat Tekan Beton Program Studi Teknik Sipil Fakultas Teknik Universitas Pasir Pengaraian.

[2] Sutopo, Trias Wurgandini, Abdul Harits Amrullah. (2015). Pemanfaatan Limbah Serbuk Kayu Sebagai Produk Kerajinan Dan Asesoris Interior Dengan Teknik Cor Dan Press Di Desa Panggungharjo, Bantul Yogyakarta Jurusan Kriya, Institut Seni Indonesia: Yogyakarta

[3] Tjetjep Rohendi Rohidi. (2000). Kesenian Dalam Pendekatan Kebudayaan. STSI Bandung Press: Bandung.

[4] Wijaya, Cindy., Yusita Kusumarini., Filipus Priyo Suproho. (2015). Perancangan Portable Folding Furniture Untuk Interior Apartemen Tipe Studio. Jurnal Intra Vol.3,No.2,(2015)9-17.

[5] Wulandari, Indrarini Feny. (2011). Pengaruh Penambahan Serbuk Gergaji Kayu Jati (Tectona Grandits L.f), Pada Paduan Tanah Liat Abu Sampah Terhadap Kualitas Batu Bata Merah di Kabupaten Karang anyar. Dalam Skripsi: FMIPA, UNS.

[6] https://id.wikipedia.org/wiki/Mebel diakses pada tanggal 17 Januari 2016.

[7] https://jasafurniture.wordpress.com/bahan-baku-furniture/ diakses pada tanggal 17 Januari 2016. 